\title{
The Jewishness of Jesus and ritual purity
}

\author{
CECILIA WASSEN
}

$\mathrm{T}$ oday it is commonplace for historical Jesus scholars to emphasize Jesus' Jewishness. At the same time most New Testament scholars deny that he cared about the Jewish purity system, which was a central aspect of early Judaism. This article examines how such a reconstruction of the historical Jesus would influence his Jewishness, arguing that it indeed would make such a Jesus figure 'less Jewish'. The article also investigates questions concerning what Jewish identity in the late Second Temple period entails and how we may characterize the Judaism of Jesus' time, especially in relation to purity concerns. Finally, l examine key Gospel texts that are commonly used as evidence to prove Jesus' alleged disinterest in purity laws. On the basis of a proper understanding of how the purity system functioned in Jesus' time, I conclude that there is no evidence for the view that Jesus was disinterested in matters of purity; quite the opposite.

\section{The Jewish identity of Jesus}

In the last few decades biblical scholarship has deepened our understanding of Judaism in the late Second Temple period. Our perspective on Jesus and the early Jesus movement has changed accordingly. Thanks to the great works of Geza Vermes, E. P. Sanders, Paula Fredriksen, and others, who have presented a Jesus who is very much a product of his cultural milieu, it is now commonplace to consider Jesus as a Jew, not only at birth, but also at death. Earlier generations of New Testament scholars, especially prior to WWII, did not hesitate to present Jesus over and against the Judaism of his day by highlighting his alleged rejection of Jewish laws. Judaism was often depicted in negative terms, characterized by petty legalism and focused on a work ethic, in contrast with the religion of grace and forgiveness which was offered by Jesus and Paul (for descriptions, see Heschel 2009: I 52-61, I75-200; Arnal 2005: 8-I4). Nevertheless, there were notable exceptions among Christian biblical scholars who engaged critically with Jewish traditions and presented Judaism in a more nuanced way (see Möller 2015: 90-I04). Among non-academic Christians, Jesus' Jewishness is still, unfortunately, highly controversial, as Amy-Jill Levine posits in her 2007 book, Jesus the Misunderstood Jew: The Church and the Scandal of the Jewish Jesus. Although she is writing for an American 
audience, the book is a valuable corrective in the Nordic context also. Today overtly negative evaluations of Jewish practices and beliefs are rare in scholarship and scholars repeatedly emphasize that they present a 'Jewish Jesus'. In the r 970 Geza Vermes emphasized Jesus' Jewish identity in his book, entitled Jesus the Jew (1975). So also did John Dominic Crossan (The Historical Jesus: The Life of a Mediterranean Jewish Peasant, I99I) and John P. Meier (Jesus the Marginal Jew, I99I). In fact, the recent phase of research into the historical Jesus - 'the Third Quest' - has been characterized by its placing of Jesus within Judaism. Tom Holmén explains: 'the estimate of today's Jesus scholars is that a constitutive factor clearly distinguishing the "Third Quest" from the previous phases of Jesus research is precisely its laying a clear emphasis and stress on the Jewishness of Jesus' (Holmén 2001 a: I 43).

At the same time as scholars emphasize the Jewishness of Jesus, the majority of them claim that he dismissed the Jewish purity system, which was a basic feature of early Judaism. Contrary to most New Testament scholars, I contend that there is no evidence for the widespread view that Jesus challenged the purity system, which I will demonstrate below. A related issue that I will also discuss probes whether historical reconstructions of a Jesus who dismisses purity laws negatively affect his Jewishness. Hence, I will also address the thorny issue of Jewish identity as it applies to Jews in antiquity; what did 'Jewishness' in antiquity entail?

\section{Jewishness and common Judaism}

What do scholars mean when they highlight Jesus' Jewishness? We can assume that scholars do not primarily refer to his ethnic identity, since no serious scholar doubts that Jesus was a Jew in that sense; rather, the emphasis on his Jewishness denotes his cultural and religious identity, which goes hand in hand with an ethnic identity, forming a sort of 'communal identity'. ${ }^{1}$ The insistence

1 Since non-Jews could enter into the Jewish group through religious rituals - becoming either full members through conversion (circumcision for men) or God-fearers - the tie between Jewish religion and ethnic identity is weakened. Shaye Cohen (1999: 3) points to a 'progression from ethnicity to religion from Hasmonean times' (p. 3 ). This openness to non-ethnic Jews is part of a trend in the Greco-Roman world in which the cults in general became increasingly independent of ethnic identities. Anders Runesson (20 I I: I 33-5 I) describes 'de-ethnosizing processes' in relation to cults, such as those of Isis, Serapis, and Mithras. A Roman person, for example, worshipping Isis in Rome did not become an Egyptian. In my study, Jewish identity refers to expressions of belonging to a primarily (but not exclusively) ethnic group by accepting and conforming to the customs, beliefs, and practices of that particular group. 
on Jesus' Jewish identity in the I970s and I 980 s was an important corrective to older, and often derogatory views of early Judaism. But it is odd that scholars still feel a need to assert the Jewishness of Jesus, as James Crossley (2008: I77-89) points out, as if anyone would doubt the fact that Jesus was Jewish. In comparison, for example, no Swedish historians would highlight the Swedish identity of the country's famous king, Gustav Vasa; no book about him would be entitled, Gustav Vasa, the Swedish King. On the one hand, the assertion of Jesus' Jewish religious identity may simply be a way of encouraging the readers to look behind 2,000 years of church history, which is a challenge. On the other hand, the emphasis may reveal an apologetic tendency among scholars to stress that Jesus was indeed Jewish in spite of reconstructions that portray Jesus as quite distinct from other contemporary Jews. According to William Arnal, it is quite commonplace among Jesus scholars to 'safeguard the Jewishness of Jesus', perhaps as a response to what he describes as 'a proliferation of charges that certain contemporary reconstructions of the historical Jesus are un-Jewish or even - it is implied - anti-Jewish' (Arnal 2005: I6). Among the targets of such a critique are John Crossan, Leif Vaage, and Burton Mack, whose Cyniclike Jesus is sometimes seen as un-Jewish. The Jesus Seminar, which produces a non-apocalyptic Jesus largely on the basis of the sayings of Jesus (as found in the alleged early layers of $Q$ and the Gospel of Thomas) is also subject to similar criticism. John Meier, for one, makes the charge that 'especially among certain authors now or formerly connected with the Jesus Seminar, emphasis on the Jewishness of Jesus is hardly a central concern' (Meier I 99I-2009, III: 3-4). Other critics include Birger Pearson, Hans Dieter Betz, and E. P. Sanders (Pearson I996; see Arnal 2005: I7). The latter finds an anti-Jewish bias in the analyses of many historical Jesus scholars. Although Sanders does not suspect them of having personal anti-Jewish sentiments, he alleges that they are ignorant in general of ancient Judaism and often dislike ancient cultures (Sanders 2002). In a similar vein, Crossley claims that many contemporary scholars still assert Jesus' uniqueness and superiority by reconstructing a 'Jewish-butnot-that-Jewish' Jesus, that is, a Jewish Jesus who is still very different in some ways from contemporary Judaism (Crossley 2008: I 73-99; Crossley 2013). He points to tendencies to differentiate Jesus from others in several areas, especially halakhah (Torah observance), but also in his views on women, on forgiveness, the temple, and so on. He highlights statements such as N.T. Wright's concerning the presention of 'a very Jewish Jesus who was nevertheless opposed to some high-profile features of first-century Judaism' (Wright r 996: 93). That scholars find a way to demonstrate that Jesus transcends, intensifies, ignores, or challenges 'at least one key symbol of Jewish identity' is a current trend in 
scholarship today according to Crossley (20 I 3: I I6-I 7). For this study, the following statement by Michael Bird demonstrates such an attitude, with a focus on Jesus and purity: 'I am inclined to identify Jesus as essentially Torah compliant, but also recognize the fact that he challenged and flouted many of the legal interpretations of his contemporaries. One particular area of disagreement appears to be in matters relating to purity...' (Bird 2008: I6). Would such a reconstruction make Jesus less Jewish, or in Crossley's terminology, 'Jewish but not that Jewish'?

In this context Arnal's analysis and critique of the debate over the Jewish Jesus is relevant. He states, '... in terms of current, mainstream scholarship in North America and Western Europe, the non-Jewish historical Jesus is a classic straw man, a way of characterizing the views of one's opponents as selfevidently false', adding that this critique by itself demonstrates how self-evident the Jewishness of Jesus is for most scholars (Arnal 2005: I9). Thus, in his view, it is unfair to criticize scholars of a Cynic-like Jesus such as Crossan, for example, for making Jesus un-Jewish, when they assert the opposite and ambitiously attempt to uncover Jesus' Galilean context, which included both a Jewish and a Greek population (ibid. 25-9). Importantly, Arnal emphasizes that historians have to account for real diversity in any ancient culture: 'Real people - even Jews! - have different views and behave in multiple ways' (ibid. 3 I ). Similarly, Tom Holmén points to the heterogeneous character of Judaism in Jesus' time, arguing that scholars have to allow Jesus to have been both different and Jewish: 'historical Jesus study must now reengage in the quest for a different Jesus' ... and, 'this is our only way forward as long as we continue to regard the Judaism that formed Jesus' context as heterogeneous and diverse' (Holmén 201 3: 533). ${ }^{2}$

Of course, the critique of scholarly reconstructions of Jesus as being unJewish depends on how we define the concept 'Jewish identity', that is to say as a communal religious and cultural identity in the first-century Judean/ Galilean context. Or, put differently, what makes a reconstruction of Jesus unJewish? Which criteria should be applied for this assessment? This difficulty makes it even more important that scholars explain what they mean by the term 'Jewish' in regard to Jesus, which, incidentally, Crossley leaves out of his discussion. In addition, a definition of Jewishness has to be useable. Sometimes New Testament scholars define Jewishness so broadly that it virtually loses all its meaning. An illustration (although extreme) of this is provided by Donald Hagner, who in a critical survey of Jewish approaches to the study of Jesus 
exclaims, 'What must be said as forcefully as possible is that the kerygmatic Christ of the Gospels is fully Jewish [italics in original]. Acceptance of the entire narrative of the Gospels tradition entails no denial of Jesus' Jewishness'(Hagner I997: 84).

A Jewish religious/cultural identity depends on how one characterizes firstcentury Judaism, which is especially difficult since Judaism in Palestine was highly diverse and included many sects. One may point to certain basic practices that are uniquely Jewish; for example, circumcision, Sabbath observance, avoidance of pork, and the worship of one invisible God. These characteristics are well known by ancient non-Jewish writers, who are especially fascinated by the subjects of the Sabbath and pork (Sanders 2008: 20; Barclay I996). Sanders's description of a 'common Judaism' is highly useful as he focuses on 'a pattern of religion' that includes both practice and basic beliefs, importantly about God's grace and the covenant upon which Torah observance is based. His starting point is to find what 'the priests and the people would agree upon', that is, 'common' Judaism, which was in a sense also normative, since it was shared by the majority of the people (Sanders r 992: 47). By defining a 'common Judaism', rather than a mainstream Judaism, various sects are included. Concerning common Jewish practice, Sanders highlights worship, supporting the temple (paying temple tax, making offerings etc.), keeping the Sabbath, circumcision, purity observations, and diet (ibid. 235-40). The last four practices in particular serve as identity markers of Jews, while 'details of Sabbath and purity practices also identify different groups within Judaism' (ibid. 235). An important aspect, or 'common denominator', of early Judaism is the theology, which he characterizes as 'covenantal nomism'. This definition also provides an answer to his key theological questions; how to get in (covenant), and how to stay in (nomism). In polemical rhetoric against much of previous New Testament scholarship Sanders explains: 'Legal obedience was founded not on the (entirely hypothetical) principle that each individual must earn salvation by compiling merits, but rather on the (well-supported) principle that this is what God, who chose the people, specified as the way they should live' (Sanders 2008: I 3). He clarifies that the major beliefs which make up 'covenantal nomism' are faith in the one God and the belief that his will is found in the Hebrew Bible, including laws and notions of election (ibid. 23).

While Sanders has received wide acclaim for correcting earlier scholarship (e.g., Cohen 2008), he has also acquired critics, including from some unexpected scholarly quarters. According to Philip Alexander, Sanders emphasizes Jewish beliefs, for example, grace and forgiveness, at the expense of the legal character of first-century Judaism, in effect turning early Judaism into 
a Protestant, watered-down version of the religion (Alexander r 986). ${ }^{3}$ In a similar line of critique, Jacob Neusner alleges that Sanders brings questions derived from Christian theology to early rabbinic literature, which means that he misses the core of Mishnah's concerns. Yet, at the same time, Neusner finds 'the fundamental nature of the covenant conception' in early rabbinic literature according to Sanders description 'self-evident' (Neusner I 978: I77). This statement in fact supports Sanders's claim that Torah observance is founded on a covenantal theology, which many New Testament scholars have missed. But Neusner, supported by Bruce Chilton, argues that Sanders's presentation of covenantal nomism 'yields little that is more than simply banal' (Chilton and Neusner I995: I 5). Furthermore, Chilton and Neusner criticize Sanders for harmonizing diverse types of Judaism, arguing that these various forms of Jewish religiosity should more accurately be labelled 'Judaisms': 'Does he then tell us the distinctive viewpoint of each [source]? Not at all. All he wants us to know is are the facts common to them all?' (ibid. I4). Martin Hengel and Roland Deines (I 995: I5-I6) raise similar points of critique concerning harmonistic tendencies in an article responding to Sanders' characterization of 'common Judaism'. But, Sanders's primary concern is precisely to uncover what these distinct Jewish sources have in common, not to explain what sets them apart. In addition, Neusner had previously characterized common Judaism as based on scriptures, temple, and the practice of common people, which is not far from Sanders's description (Neusner I 984: 21; see Luomanen 2002: I I 7 ). Jonathan Z. Smith, finally, alleges that religions such as early Judaism do not have an essence (Smith I980: I-25).

Petri Luomanen explains, however, that many of his critics do not distinguish between the concepts 'covenantal nomism' and 'common Judaism' outlined by Sanders, rather seeing the former as an aspect of the latter (Luomanen 2002: I I 8). Responding to Neusner's critique, Sanders highlights the diversity within Judaism which does not invalidate its unity: 'The Pharisees, the Sadducees, the Essenes, the members of the 'fourth philosophy', the common people, the religion of "grace". But does that not involve a tacit acceptance of a major element in his opponents' position— the assumption that "grace" is superior to "law"? The correct response to the charge must surely be: And what is wrong with "legalism", once we have got rid of abusive language about "hypocrisy" and "mere externalism"? It is neither religiously nor philosophically self-evident that a "legalistic" view of the world is inferior to one based on "grace". If we fail to take a firm stand on this point we run the risk of seriously misdescribing Pharisaic and Rabbinic Judaism, and of trying to make it over into a pale reflection of Protestant Christianity.' 
Hellenistic Jewish philosophers such as Philo all disagreed on lots of points. They all belonged, however, to Judaism. Where most of them agree is where we find "common Judaism"' (Sanders 2008: r 9). He adds, "Without common or shared identity, however, Judaism might have broken into Neusner's separate Judaisms, and many more Jews would have assimilated themselves to common Mediterranean life' (ibid. 2 I ). Furthermore, Sanders makes it clear that he never claimed to have presented the essence of Judaism, for which he had been criticised by Smith, but simply common practices and beliefs (ibid. 23).

\section{Jewish identity in antiquity: a matter of perspective}

The difficulty of defining early Judaism is exemplified in the ongoing debate about the identity of early Christ-believers; at what point do they stop belonging within Judaism? That scholars differ widely on this issue demonstrates the complexity and difficulty with defining a Jewish identity in antiquity. To illustrate the problem, the Maccabees provides evidence for Hellenized Jews who have stopped circumcising their children and covering up the marks of circumcision ( I Macc. I: 15, 48, 60; 2 Macc. 6:10; cf. Josephus, Ant. I 2.254). Were they Jewish? Who decides? Furthermore, Philo condemns a group of Jewish philosophers who interpret the Mosaic laws allegorically (as Philo himself does), to the extent that they have stopped observing these laws. By holding on to the superiority of the Torah, without observing the Jewish customs, these Jews still likely maintained a strong Jewish identity. But were they 'Jewish'? Philo's nephew, Tiberius Alexander was procurator of Judea in 46-8 $\mathrm{CE}$, of Egypt in 66-70 CE, and served as Titus' second-in-command during the Jewish revolt. Was he Jewish? Josephus claims that Tiberius did not continue to involve himself 'in the practices of his countrymen' (Ant. 20.100-3). Discussing Jewish identity, Marisa James (201 2: 8) notes that 'Roman historians primarily concern themselves with whether Tiberius Alexander was a good Roman, while Josephus is concerned with whether Tiberius is a good Jew'. What would Tiberius himself have said? We do not know. We may also note the enigmatic accusation by John in Rev. 2:9, which captures the complexity of the problem head on: 'I know the slander on the part of those who say that they are Jews and are not, but are a synagogue of Satan.' In this case, a group of people identify themselves as Jews, an identity which John rejects. In this context, Arnal's colourful depiction of ancient Jews adds an important aspect by pointing to the 'messiness' of cultures: 'Even if Sanders is right that there was a form of "common Judaism" it does not necessarily follow that these generalizations apply to any particular person or group of persons. Some people reject, resist, 
or deliberately modify key, even definitional, aspects of their culture.' He points out that 'Valentinus was a Christian. Siddhartha was a Hindu. Luther was a Roman Catholic', and so forth (Arnal 2005:3 I). But when reconstructions of Jesus lack any resemblance to contemporary Judaism (albeit based on our limited knowledge of the subject), is that Jesus still Jewish? It becomes important to find a balance between reconstructing a Jesus who is historically plausible in his milieu and allowing him, just like other leading, historical figures, to also be distinctive within that milieu. But where do we draw the line between depicting Jesus as distinctive and as uniquely different from his cultural context? Arnal points to this problem when he states, 'Without insisting that he be unique, or to be understood in "opposition" to "Judaism", we should still note the possibility, even likelihood, that such an influential figure, an apparent catalyst for subsequent change, will be distinctive' (Arnal 2005: 3 I; cf. Holmén 2013).

It is important to take into consideration that Jewish identity is not a stable category, but changes from the viewpoint of different groups. For example, both the members of the Qumran movement and the groups around Paul saw themselves as the true Israel; they both claimed to belong to the true covenant of God. From their perspective they were the most Jewish of Jews. Paul included Gentile Christ-believers in his definition of being Jewish, a perspective most other Jews would dismiss completely (Rom. 2:23-9). Jewish identity depends on context and perspective, which is also evident in the ongoing conflict between the Jews and the Samaritans. From an outsider's perspective, Samaritans and Jews would be very similar in their beliefs, religious practices, language, and material culture (Knoppers 2013: 217-39). Yet, as John 4:9 explains, 'Jews do not share things in common with Samaritans'. Distinguishing themselves from Jews made up an important aspect of the communal identity of Samaritans in the time of Jesus and both Jews and Samaritans harboured a marked hostility towards each other. From this perspective 'Jewish identity' in antiquity depends on context, circumstances, and point of view; that is, when, where, and according to whom is it being defined? Shaye Cohen notes, 'Jewishness was a subjective identity, constructed by the individual him/herself, other Jews, other gentiles, and the state' (Cohen I 999: 3). Sanders addresses this issue in a reflection, written in 2008 , on his earlier work. He asks whether individual Jews who omitted half or more of the common practices and beliefs would still be counted as Jewish. He answers, 'I would say yes, if they counted themselves as Jewish and if other people saw them as Jewish. A person who gave up all of the typical practices, it would seem to me, would merge into the Gentile world. Legally, a "son of Israel" might still be a Jewish by birth; but socially, a total apostate would have removed himself or herself from the collective entity of Judaism' (Sanders 2008: 
$2 \mathrm{I}-2$ ). Here he touches on the importance of distinguishing between the different perspectives of insiders and outsiders of groups, that is between emic (internal) and etic (external) perspectives. From a sociological perspective it is important not only to take the self-understanding of groups into account, but also study them from an outside perspective as Luomanen argues. If we only focus on the insiders' perspective, then we end up with different Judaisms, lacking the analytical tools needed in order to compare different groups with each other, and sects in comparison with common Judaism (Luomanen 2002: I I 8). As historians studying religions, we need generalizations. We need categories that set one system of beliefs and practices, or religion, apart from another. For this, we need to take an outsider's perspective and study common traits within such a system. At the same time, Arnal's caution about generalizations is highly relevant when he argues that any reconstruction of a Galilean Jewish religiosity 'will provide us with a context of Jesus' teaching and activity - not with an indication of what that teaching and activity must have been' (Arnal 2005: 3 I; cf. Holmén 2013).

Overall I find Sanders's definition of a common Judaism persuasive, that is, what Jewish peasants and priests would basically agree upon in practice and belief, and his answer to that question. Hence, his description of a common Judaism is the theoretical framework I have adopted for this study of Jesus, without claiming that this is the only way that the issue can be addressed. Nevertheless, his definition is useful primarily concerning Judaism in Palestine, and to a lesser extent in the diaspora where Jews were in a minority and different social norms came into play (Barclay i 995: i i 8-20).

\section{Torah observance}

Before addressing Jesus's attitude to purity and the consequences of this for his Jewish identity, I will clarify what observance of Jewish laws entailed in the late Second Temple period. Living according to laws always meant taking part in a living tradition. Sanders poignantly affirms that Judaism was more a 'way of life' than a doctrinal system (Sanders I 992: 3 ). It is revealing that both Philo and Josephus employ the term 'the traditions of the fathers', 'customs' and similar expressions when referring to Jewish laws, just as Mark does ('tradition of the elders'; 7:3). ${ }^{4}$ Most people in Palestine would simply live according

4 Philo says about the Jewish customs, '... the particularity of their exceptional customs, not mixing with others to alter the ancestral ways' (Mos. I.278). See Josephus Ant.

I.I 92; 4.I I 4 ; J.W. 7. I IO. 
to the traditions with which they were familiar. Living according to the traditions of the fathers also meant adapting one's lifestyle according to new situations however, and this required ongoing negotiations and interpretations. Some halakbic areas were hotly debated, for example, as we see in the Dead Sea Scrolls concerning temple practice, purity practice, and observance of the Sabbath laws. The fact that several different Jewish parties appeared in the late Second Temple period - such as the Pharisees, the Sadducees, and the Essenes - that offered different interpretations of legal issues, attests to the diversity of views. The Pharisees were even divided between two houses, those of Hillel and Shammai, the latter often having a more stringent interpretation than the former. There is strong evidence that Jesus engaged in debates about the interpretation of laws, often about the Sabbath, when he often took a lenient position compared to the Pharisees (e.g., Mark 2:23-8, 3: I-6; Matt. 23). In the case of divorce, however, Jesus sided with the more stringent halakhah of Shammai in his prohibition of divorce (Matt. 5:3 I-2). In addition, his ethical teaching, which was also part of Torah observance, reflected a highly strict position (see Matt. 5:2 I-48). The Essenes (the Qumran movement) in turn, were often more stringent in their interpretation than others, and in some points agreed with the Sadducees. They accused the Pharisees for taking short-cuts in their legal traditions, calling them 'seekers of smooth things', where halaqot' (e.g., $4 \mathrm{QpNah}$ $3-4$ i 7) is a play on the words 'seekers of halakhot'; which translates as 'seekers of correct laws'.

\section{Purity}

For most peoples in the ancient world, purity and impurity were part of a basic understanding of the world. This is evident in first-century Judaism which categorized people, objects, and places as either pure or impure, holy or profane. The overarching function of purity regulations was to prevent impurity from coming into contact with the holy; most importantly the temple in Jerusalem, but also consecrated food (Harrington 2004: 9-12). Nevertheless, the spread of ritual baths (miqva'ot) all over the country demonstrates that people far from the temple also cared about purity.

The laws concerning ritual impurity appear in Leviticus I I-I 5 and Numbers. The first thing to keep in mind is that impurity is an inescapable part of everyday life. Everybody was impure at times. The most obvious example is that of sexual intercourse, which rendered both the man and the woman impure; a couple would have to bathe and wait until the evening to be pure again (Lev. I 5:I8). Of course, this kind of impurity was not something people avoided 
- on the contrary, procreation was a commandment. A woman was impure at childbirth for a length of time. Similarly, taking care of one's dead parent, which was an obligation, subjected that person to one of the most severe forms of impurity. In other words, by fulfilling certain obligations, such as the command to be fruitful and to bury one's parents, people became impure. Clearly impurity was a part of life. And, unless the source of impurity was chronic, as it would be in the case of lepers ('scale diseased') and permanent dischargers (the male zav and the female zavah), there was always a way to restore purity. We may notice as well, that biblical discourse in general conveys no negative sentiments about these carriers of impurity; instead their status as ritually impure is described in a neutral way and as a matter of fact. The basic view, as Jacob Milgrom observes, is that contracting impurity in itself was no sin (Milgrom I 99I: 298). Transgressions or sin in connection to purity laws concern defiling the sancta: the sacred sphere, in other words, the temple and consecrated food. Jonathan Klawans reiterates Milgrom's position and accuses New Testament scholars of frequently misunderstanding the ritual impurity system by identifying impurity with sin (Klawans 2006: 267).

Biblical laws in general do not even prescribe avoidance of ritual impurity, except in connection to the sacred. There are very few verses that warn against

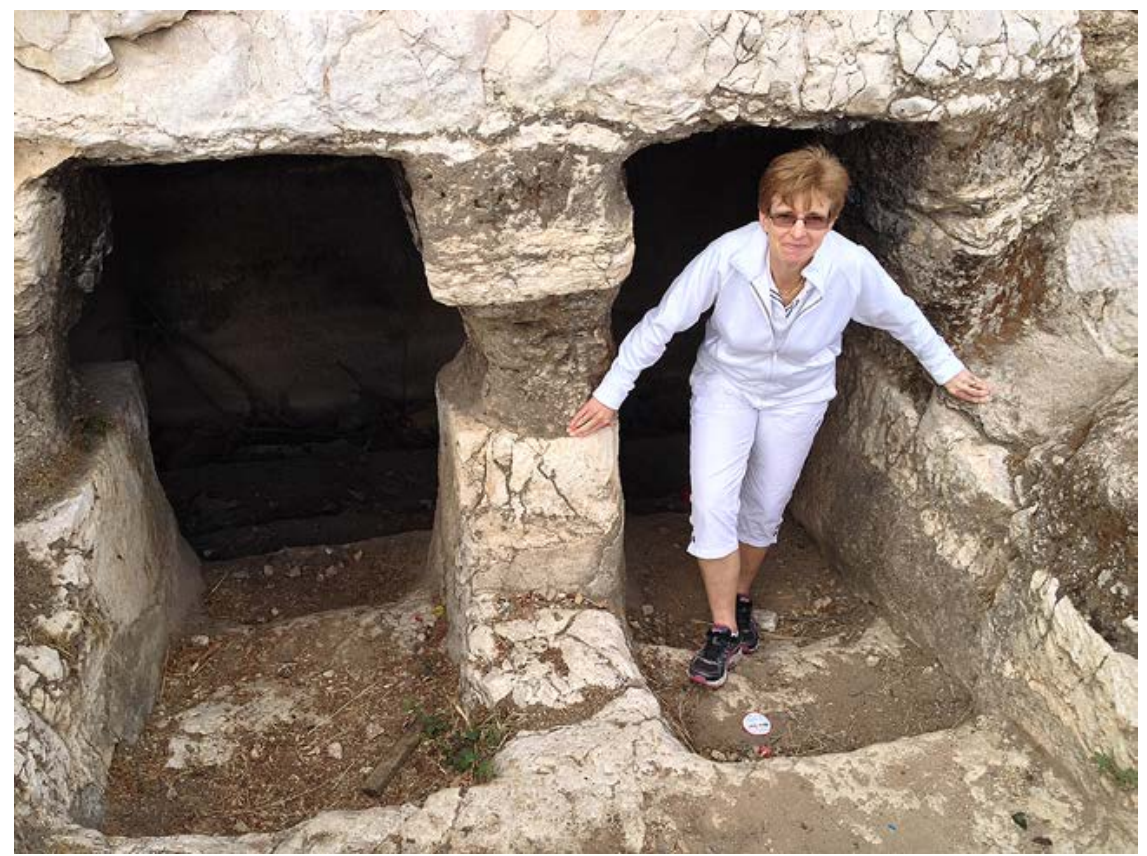

The author in an ancient miqveh outside Jerusalem. Photo by Jutta Jokiranta. 
attracting impurity or that seek to prevent impurity from occurring. Instead, the biblical laws simply clarify how to handle impurity. At the same time, there is an alternative view according to which purity is seen as the ideal state also in connection to the profane, or secular, sphere. The attempt to control the spread of impurity within the realm of the secular sphere is evident in laws that exclude the people who are affected by a severe kind of impurity from the camp of the Israelites in Numbers 5:I-4; which includes the leper, the zav, and one who is defiled through contact with a corpse (cf. Lev. I3:45-6). There are two tendencies evident in the biblical texts, as Gedalyahu Alon (I 977) explains; one that restricts impurity with regard to the sacred sphere, and one that attempts to limit impurity also within the secular sphere.

Purity practice is a fundamental part of common Judaism according to Sanders. He rightly claims that after circumcision, purity regulations were 'the most obvious and universally kept set of laws' (Sanders I 992: 2 I 4). The infected debate about purity among Jewish sects testifies to a deep concern over purity issues. The importance of purity is supported by archaeological evidence. Ritual baths (miqva'ot) were common in first-century Palestine, including the region of Galilee. About 850 miqua'ot dating to the turn of the era have been discovered in Israel (Adler 20I I). Other typical Jewish artefacts are stone vessels (vessels, cups, and bowls) which likely also signify a concern about purity, since these could not become ritually impure. These have also been found in Jewish villages and towns all over Palestine (Mizzi, forthcoming; Berlin 2005). Both the spread of ritual baths and stone vessels testify to a general concern about purity, or even to 'a purity wave' in Jewish society according to Hørning Jensen (2013). Thus, if Jesus did not care about purity laws, it would put him in conflict with a fundamental aspect of Jewish practices, and make him 'less Jewish'.

\section{Scholarly views on Jesus' attitude towards purity}

Jesus' actions concerning the sick and the dead, and the conflict over pure food (Mark 7), have traditionally been understood as evidence of Jesus' rejection of the purity laws in general. Apart from touching sick, impure people, Jesus was also known for sharing meals with sinners, which also contributes to the assumption that Jesus rejected the purity laws. At the same time the very central description of Jesus' own purification rite, that is, his baptism, has largely been ignored in interpretations of Jesus' attitude towards purity issues. Importantly, some scholars - for example, James Crossley (2004) and Paula Fredriksen (1999: 197-207) - do not find evidence that Jesus challenged the purity laws, but this view remains a minority position. 
A thorough study by Thomas Kazen (2002) of Jesus' attitude to purity laws; Jesus and Purity Halakbah, subtitled, 'Was Jesus Indifferent to Impurity?' moved the discussion forward considerably. His study has encouraged scholars to debate not so much whether Jesus outright rejected the purity laws, but rather to what extent he cared about the purity system. Kazen's answer to his own question, 'Was Jesus indifferent to impurity?' is affirmative: 'Jesus' behavior may be understood as indifferent, and there are signs that it was interpreted as such by his adversaries' (Kazen 2002: 344; cf. Kazen 2013: I I 8). ${ }^{5}$ Kazen's study has been highly influential, and major historical Jesus scholars, such as James Dunn (2002: 46I and 2003: 789) and John P. Meier (199I-2009, IV: 4I5), tend to agree with Kazen. According to Dunn, touching a leper in Mark $1: 40-5$ is a primary example of Jesus' disregard for purity concerns in that gospel, and he adds a whole list of instances that demonstrate Jesus' 'casual approach to impurity' in Mark which is 'firmly rooted in tradition' (Dunn 2003: 789). For Meier the 'seeming indifference' to purity laws on Jesus' part that Kazen finds, becomes 'a studied indifference' (Meier I99I-2009, IV: 4I5) for which Kazen criticizes him (Kazen 2010: I67). Recently, Holmén, one of the two editors of the massive, four volume Handbook for the Study of the Historical Jesus (Brill), argues that Jesus understood his dealings with the ritually impure as 'making the unclean clean', thus, in effect inverting the ordinary purity rules so that Jesus would transfer purity to others rather than himself being susceptible to impurity (Holmén 20I I). In his book Pure Kingdom: Jesus' Vision of God, Bruce Chilton (1996) emphasizes that purity is at the centre of Jesus' vision for the kingdom. But according to Chilton, purity for Jesus is something completely different than traditional ritual purity and applies to everyone who enters the kingdom. Purity was not attained by merely washing; rather the whole person was either clean or unclean: 'Jesus asserted that purity was a matter of the

5 At the same time, Kazen does not claim that Jesus rejected the purity system altogether, but that he 'relativized' it and to some extent 'disregarded' impurities. Kazen asserts that Jesus still operated within the basic purity paradigm, though pushing the boundaries to breaking point for many onlookers (2002:346). These points that weaken Jesus' indifferent' stance towards impurity are rarely noted. Also Holmén (ibid. 236-7) argues that Jesus was indifferent to purity laws, but that he could also comply with them e.g., when he entered the Temple at Passover. Holmén (ibid. 237) concludes, 'He [Jesus] found generally no hindrance in complying with the laws, but could defy them just as well. Correct words to describe this kind of attitude are disinterest and depreciation.' I disagree with him that there is any evidence that Jesus defied purity laws. 
totality of one's being. ${ }^{6}$ The idea that Jesus somehow spread purity and holiness to others through his healings and acceptance of sinners has become increasingly popular among Jesus scholars, such as Bruce Chilton (I998: 58-7 I), Craig Evans ( I 997: 368-9), Crispin Fletcher-Louise (2007: 65), James Dunn (2002: 46r), and Michael Bird. According to Fletcher-Louise there is even an 'emerging consensus' among scholars that Jesus' healings implied a contagious purity (2007: 65). For example, Bird (2008: 24) argues that Jesus radically redefined purity on the basis of his conviction that the eschatological promises of cleansing and forgiveness (Zech. I3:I; I4:8, 20-I) had been fulfilled:

This Zecharian vision of holiness has arguably become a controlling principle for Jesus' ministry where it drives the redefinition of purity within Judaism as it is holiness rather than impurity that acts as a contagion. Much like the gushing out of water from Jerusalem in Zechariah, Jesus 'by touching people turns them from impure Israelites into pure Israelites'. (Bird 2008: 24)

There is no room to enter into a discussion on these suggestions; suffice it to say that their Jesus has a thoroughly different view of purity compared to his fellow Jews. Consequently, Kazen dismisses the notion of a dynamic purity as advocated by Holmén and Chilton as speculative (Kazen 2013: 122). ${ }^{7}$ In traditional Judaism, impurity was transmitted between people, but purity was obtained through divine agency, that is through God or the Holy Spirit. If Jesus had actually believed that he was transmitting purity to others, then this Jesus would have had an extremely elevated view of himself as a divine representative, a suggestion that I find highly problematic. ${ }^{8}$

According to Chilton (2000: 87) Jesus interpreted such a mission based on Ezekiel's vision in Ezek. 36:25-6 of God pouring out his spirit and purifying Israel; see also Chilton I992: I 23-5, I 42 .

7 Kazen compares Holmén's views with those of Chilton and concludes: 'Chilton's views are accepted by few, however, because of their fanciful and overly detailed reconstructions, which in any case have little to do with purity halakah' (Kazen 2013: I 22 ).

8 There is, unfortunately, no room in this short article to go into questions of Jesus' selfunderstanding. I can only point to Kazen's convincing conclusion that Jesus' engagement in debates over legal issues 'does not demand a portrait of Jesus as displaying the unique kind of authority that is often ascribed to him'. Instead, as an eschatological prophet Jesus was motivated by a utopian vision of restoration and the model of his mission was informed by prophets of the past who like Jesus were offering social critiques. (Kazen 2013: 293-302) 


\title{
The key Gospel texts concerning Jesus and purity
}

The key stories that have been interpreted by scholars as showing Jesus disregarding purity concerns are: the healing of a leper (Mark $\mathrm{r}: 4 \mathrm{O}-5)$, the healing of the haemorrhaging woman and the raising of the girl (Mark 5:2 I-43), and the hand-washing controversy (Mark 7:I-7, I4-23). For most part, I will not go into the tricky questions concerning what specifically may be historically accurate or not. I will simply take these and other stories about Jesus' healing activities as early accounts of a person who did not shy away from healing the ritually impure, including people with a serious form of skin disease ('lepers'), and from entering the houses of the dead - I think this general recollection is accurate (e.g., Dunn 2003: 789). That Jesus also had meals with 'sinners' is widely attested in the Gospels.

The first 'evidence' of Jesus' casual approach to impurity is the story about his healing of the the man with skin disease in Mark $1: 40-5:{ }^{9}$

\begin{abstract}
A leper came to him begging him, and kneeling he said to him, 'If you choose, you can make me clean.' Moved with pity, Jesus stretched out his hand and touched him, and said to him, 'I do choose. Be made clean!' Immediately the leprosy left him, and he was made clean. After sternly warning him he sent him away at once, saying to him, 'See that you say nothing to anyone; but go, show yourself to the priest, and offer for your cleansing what Moses commanded, as a testimony to them'.
\end{abstract}

In this story, Jesus commands the healed leper to act according to the prescriptions in Lev. I3-I4 concerning a leper who is free of his or her symptoms. First, we should note the obvious: the story is not presented as one portraying a conflict in any way. In other words, Mark does not lead his audience to interpret the story as an example of how Jesus challenged Jewish laws (contra e.g., Chilton 2000: 89-90). Instead, the story is a testimony of Jesus' healing power. It is also evident that this record shows Jesus respecting and encouraging observance of the laws concerning the purifications which include examination by a priest and the offering of a sacrifice (Lev. I3-14). Even Dunn takes this part of the story as evidence that 'Jesus himself shared at least some purity priorities' (Dunn 2002: 449). It is quite amazing that some scholars still manage to construe the story to show the opposite; namely that Jesus disregarded purity rules. Hence, Holmén focuses on the wording of Jesus: 'be clean', katharisthèti, 
emphasizing that Jesus declared the man clean prior to his cleansing rituals (Holmén 201r: 27I5-I6). Several aspects of this line of interpretation are problematic, however. First, I find the heavy reliance on Mark's precise wording (in Greek!) that is placed in Jesus' mouth quite remarkable. Second, in this context the verb 'to cleanse' functions as a synonym for 'to be cured'. ${ }^{10}$ But, the overall mistake is to assume that all Jews would have avoided impurity to the greatest extent possible (and since Jesus did not, he would have been different), an assumption that I find faulty. Similarly, Crossan argues that Jesus' words 'sets Jesus' power and authority on a par with or even above that of the Temple itself' (Crossan I 99 I: $32 \mathrm{I}-3$ ). In his view, the command by Jesus to the leper to observe the purification laws commanded by Moses contradicts the first part of the story. He solves the 'problem' by dismissing the second part as a later addition to the first, allegedly original part. The interpretive agenda behind this kind of reasoning is quite obvious.

It is evident that Jesus physically touched sick people in the course of his healing activities, even when they were impure. But there is no example in any of the healing stories that Jesus' touching them is noted as anything strange, or that he in any way would have challenged contemporary norms concerning ritual purity regulations (Levine 1996: 379-97). Nevertheless, the secret touch of the haemorrhaging woman is an important aspect of the plot in Mark $5: 27-32$, but only to highlight Jesus' magical nature and powers. Given that the woman is suffering from an impure discharge ( $a$ zavah, see Lev. I 5:25-30), and touches the fringes of Jesus' cloak she would perhaps also transmit impurity to him, although this is uncertain (Wassen 2008: 64I-60). Either way, the aspect of impurity is simply ignored by Mark. Mark has placed this story within a different story of Jesus raising up a dead girl (Mark 5:2 I-24a, 35-43), thus linking the two. In the latter story by entering a house of a dead person, Jesus would have attracted corpse impurity, a circumstance that, again, is not mentioned by Mark. Neither is Jesus' proximity to a corpse singled out by Mark as strange or noteworthy behaviour. This silence on matters of impurity does not prevent interpreters from surmising that purity is a key part of the story anyway, as I will exemplify by engaging with Craig Evans's ( 1997) interpretation. To him both stories (Mark 5:2 I-43) send a strong message concerning Jesus' stance on purity: 'Issues relating to purity are also [just like faith] common to

10 It should be noted that both Jesus and the 'leper' use the verb (Mark I:40, 4I). See also LXX 2 Kings 5:IO-I4 where the term katharizō is used four times with reference to the healing of Naaman who has suffered from leprosy. He is miraculously 'cleansed' from his leprosy by immersing seven times in the River Jordan. 
these stories, for in the one Jesus is touched by an impure woman, and in the other Jesus touches a corpse.' And further, 'The healing of the woman with the haemorrhage is as much a purity miracle as anything else. Instead of conveying uncleanness to Jesus, whom she touches, cleanness is conveyed to her.' Concerning the story about the girl, Evans explains that Jesus was under no obligation to 'render himself unclean through contact with a corpse', since he was not related to the family. He concludes, 'His [Jesus'] willingness to touch the unclean and make it clean appears to have been a major element in his ministry' (Evans I 997: 368-9). In contrast to many commentators who take the opportunity to explain the alleged negative consequences of purity laws of the Jewish society, Evans is careful not to say anything to that effect. Still, his Jesus espouses a very different view of purity compared to views prevalent within common Judaism; Jesus in person and through his presence offers purity to his followers, which is far removed from standard, ritual purifications.

Evans fails to take into consideration that it would have been normal for a healer to touch the people whom he was attempting to heal; healing the patient by means of touch would have been as normal then as it is today (Wassen 20r6). The reason why no Gospel author notes that Jesus acted strangely when he touched the impure, was probably because they did not see anything odd in his behaviour concerning purity. Furthermore, as Sanders and others emphasize, it was no sin to become impure. Impurity was a common part of life. One important feature in the story of the dead girl is ignored by commentators like Evans; namely, the crowd in the house. Jesus forced all but the girl's parents (and his closest disciples) out of the house. Apparently, like Jesus, the villagers were not concerned about contracting impurity. This facet of impurity is simply part of the backdrop, a common part of Jewish life. In general, Mark appears to have good knowledge of Jewish society in the first century, and I assume that his general description of what would happen in a village when someone died is accurate.

Mark 7:I-23 is a key text concerning purity. In this story Jesus' disciples are asked by the Pharisees why they do not wash their hands: 'Why do your disciples not live according to the tradition of the elders, but eat with defiled hands?' Here the issue of purity is explicitly addressed. Subsequently Jesus accuses the Pharisees of hypocrisy, and implies that the rule concerning hand washing is not a biblical law, but a one traditional one: 'You have a fine way of rejecting the commandment of God in order to keep your tradition!' ${ }^{11}$ After chastising the Pharisees he gives a speech on pure and impure food:

11 Mark 7:IO-I3 reads: "For Moses said, "Honor your father and your mother"; and, "Whoever speaks evil of father or mother must surely die". But you say that if anyone 
Listen to me, all of you, and understand: ( $\mathrm{I}_{5}$ ) there is nothing outside a person that by going in can defile, but the things that come out are what defile. ( 7 ) When he had left the crowd and entered the house, his disciples asked him about the parable. (I 8 ) He said to them, 'Then do you also fail to understand? Do you not see that whatever goes into a person from outside cannot defile, (I 9) since it enters, not the heart but the stomach, and goes out into the sewer?' (Thus he declared all foods clean.) (20) And he said, 'It is what comes out of a person that defiles. (2 I) For it is from within, from the human heart, that evil intentions come: fornication, theft, murder, (22) adultery, avarice, wickedness, deceit, licentiousness, envy, slander, pride, folly. (23) All these evil things come from within, and they defile a person.'

Mark 7:I-23 includes a combination of disparate topics, but scholars disagree as to the precise division of them. In agreement with Roger Booth and Kazen I accept that Jesus' replies in verses 6-7 and 9-I 2 are distinct from each other and have been put together by Mark (Booth I986: 71-4; Kazen 2013: I I 7, I 79). Kazen makes a strong argument in support of the idea that the criticism concerning the conflict between biblical law and human traditions and the Isaiah citation ( $7: 6-9)$ reflects the period of the early church (ibid. I 79). A key feature of the debate, concerning corban (7:9-12) however, may stem from Jesus' time (Booth I986: 71-4; Kazen 2013: I79-80), but it is not related to purity. Furthermore, the explanations that follow 7:1 5, that is, 7:1 8-23, comprise pre-Markan material that Mark has edited (Kazen 201 3: I89-9I) and do not originate with the historical Jesus (ibid. I 87-9I). Hence we are left with a debate about hand washing and the central issue of the saying in $7: 15$, which plausibly reflects Jesus' actions and words concerning purity.

In the Hebrew Bible only priests washed their hands and feet before approaching the altar (Exod. 30:I7-2I). In Mark 7 we hear of the Pharisees washing their hands prior to meals, which is most likely historically accurate, especially given that the practice had developed considerably by the time the Mishnah was written down (c. $200 \mathrm{CE}$ ). The idea that washing hands would remove impurity is a non-biblical innovation and aimed at preserving the purity of the people eating the food (Furstenberg 2008: 189-90). It assumes that impurity of the hands could be disassociated from the rest of the body. We do

tells father or mother, "Whatever support you might have had from me is Corban" (that is, an offering to God) - then you no longer permit doing anything for a father or mother, thus making void the word of God through your tradition that you have handed on. And you do many things like this.' 
find a similar idea in connection to the male discharger, the zav, who would not transmit impurity with washed hands according to Lev. I 5: I I. Either way, the point in Jesus' critique is that he does not agree with the Pharisaic innovation of hand washing. This tradition affirms that Jesus did not agree with the expansionist view concerning purity of the Pharisees. It does not indicate, however, that he was indifferent (or 'seemingly' so) to matters related to purity.

Jesus' words in Mark 7:I 5 are at the centre of the scholarly debate: 'There is nothing outside a person that by going in can defile, but the things that come out are what defile.'Traditionally there has been a consensus in New Testament scholarship in favour of the authenticity of Jesus' saying in 7: I 5 (Svartvik 2000: 3-8; Räisänen [1982] is an exception). Since discontinuity with Judaism was considered an argument in favour of authenticity in an earlier period of modern scholarship, Jesus' words were also considered genuine. As Norman Perrin argued in 1967 , ' $\mathrm{t}$ ] his is perhaps the most radical statement in the whole of the Jesus tradition, and, as such, it is certainly authentic' (Perrin I 967: 150). Jesus' words were also considered to be radically different from common views on purity in Judaism (see Räisänen I982). Today the authenticity of Mark 7:I 5 is hotly debated. John Meier asserts the unlikelihood that Jesus annulled the food laws based on a different principle: 'Coherence with Jesus' own sense of being a prophet sent to his people Israel — and not to the Gentiles — as well as coherence with first-century Palestinian Judaism (however varied and sectarian it was) would seem to argue against the authenticity of 7:I 5' (Meier I99I-2009, IV: 385 ). He also points to the controversy in the early Jesus movement concerning Jewish food laws, asking how the followers could have forgotten Jesus' message had he actually overturned the food laws in a revolutionary way? Sanders dismisses the authenticity on similar grounds (Sanders I 985:260-I). A different perspective is offered by Jesper Svartvik and Kazen who consider the saying to be authentic, but argue that it communicates a relative value judgement, comparing inner and outer impurity, that is, 'A man is not so much defiled by that which enters him from outside a he is by that which comes from within' (Kazen 2002: 66, 228-3I; cf. Kazen 2013: I 90; Svartvik 2000: 405-II). In Kazen's words, 'the idea that Jesus would have intended to abrogate food laws in general is out of the question' (Kazen 2013: I 82).

But if we take the saying in an absolute sense, a different message may yet emerge. Yair Furstenberg (2008) argues that Jesus' central saying makes sense in a first-century Jewish debate about purity halakhah. In a continuation of the dispute on the rinsing of the hands prior to meals (Mark 7:I-5), Jesus' statement in $7: 15$ is directed against the Pharisaic view that defiled food would render a person impure (Furstenberg 2008: I 84). In Pharisaic halakhah, washing hands 
prior to meals was a safeguard against polluting the food (especially moist food) that in turn would pollute the body (of self and others). This understanding of the transmission of impurity, which Jesus disputes, is novel compared to the laws in Leviticus. Therefore, Jesus contrasts the intake of defiled food that does not contaminate with things that go out of the body (bodily fluids) that defile a person, that is, menstrual blood, semen, and discharges (Lev. I5). The saying likely does not refer to prohibited food such as pork, which is not a debateable issue in the first century (Kazen 2002: 86) (although, technically prohibited food does not usually render a person ritually impure; see Furstenberg 2008: I 83). As mentioned, the subsequent explanations belong to later elaborations in stages. Jesus is therefore saying that defiled food does not transfer impurity by ingestion in contrast to regular, bodily discharges, which do. Since the subsequent elaborations likely reflect a later, spiritualised interpretation of Jesus' halakhic statement, his saying should not be understood in light of them. Even if we were to accept a relative understanding of the saying (ritual purity is less important than moral purity) there is still no evidence of a critique per se of the purity system.

Like many other scholars I take Mark's explanation 'Thus he declared all foods clean' (7:19) as reflecting Mark's own view in the context of the debate over food at the time of his writing (c. $70 \mathrm{CE}$ ). In comparison, Matthew chose to skip Mark's comment in his rewriting of the story (Matt. I 5:I 7). Matthew's interpretation, which he provides at the end of the discourse, however, may be closer to the original sense of Jesus' teaching: 'These are what defile a person, but to eat with unwashed hands does not defle' (Matt. I 5:20, my italics).

In addition to these specific gospel stories (the healing stories; the handwashing controversy; and the sayings about food) scholars point to the firm tradition that Jesus ate with 'sinners' (e.g., Mark 2:15-17; Matt. I I:I9), and since these people most likely included those who did not observe the halakhah properly (and did not purify according to norms), Jesus would have become ritually impure. Bird, for example, finds Jesus' lack of concern about contracting impurity 'shocking and anti-social' (Bird 2008: I6n58). On this issue I will first simply clarify that eating with morally and ritually impure people was not a sin (see Crossley 2006: 75-96). Second, the whole argument rests on the assumption that Jews in general actively avoided impurity. Given that most married men and women had sex on a regular basis and therefore quite often were ritually impure, this assumption appears faulty. It is evident that certain groups in the society of the time would have made more of an effort than others to avoid contracting unnecessary impurity; that is, priests, the Pharisees, and the 
Essenes - but their lifestyle was quite extreme compared to the people in general (which the name 'Pharisees' - separated ones - seems to imply).

If Jesus' practice concerning purity issues were shocking at the time, then we should expect to find traces of this in the gospels. Instead, there is no hint that his kind of 'open table' fellowship raised concerns about purity issues; Jesus is rather being criticized for defying social norms, according to Matt. I I: I 9 (Luke 7:34), and for being 'a friend of toll collectors and sinners' (cf. Mark 2:1 5-16; Matt. 9:10-I I; Luke 5:29-30). In the gospels we also find accusations against Jesus for being 'a glutton and a drunkard' (Matt I I: I9) and for being possessed by a demon (Mark 3:2 I-2), but there is no critique against him for transgressing purity norms. Furthermore, there are traditions in the Gospels that demonstrate that Jesus accepted the purity system. I have already mentioned that the Gospels record how Jesus underwent a purification bath - at his baptism - which establishes that Jesus did, like others, occasionally undergo purification rituals. In addition, two passages demonstrate that Jesus worked within a common purity paradigm, just as in the case of Mark r:40-5. The saying in Matt. 23:25-6 shows that Jesus distinguished between ritually pure and impure vessels; 'Woe to you, scribes and Pharisees, hypocrites! For you clean the outside of the cup and of the plate, but inside they are full of greed and self-indulgence. You blind Pharisee! First clean the inside of the cup, so that the outside also may become clean.' And finally, the saying in Matt 23:27 implies that Jesus accepted the concept of corpse impurity: 'Woe to you, scribes and Pharisees, hypocrites! For you are like whitewashed tombs, which on the outside look beautiful, but inside they are full of the bones of the dead and of all kinds of impurity.' 12

\section{Conclusion}

There is no evidence that Jesus transgressed, challenged, or disregarded purity laws. Still, most New Testament scholars attempt to argue in different ways that he did. In many cases, such conclusions are based on the, in my view faulty, assumption that Jews in general went to great lengths to avoid impurity - but we only have to consider the fact that having sex rendered a couple impure

12 These sayings belong to the Q-tradition, which is early. The ending of Luke I I:39-4I (= Matt. 23:25-6) reads: 'So give alms for those things that are within; and see, everything will be clean for you.' Only Matthew's version is historically plausible in light of the legal debates in Jesus' time. Luke i r:44 (= Matt. 23:27) reads: 'Woe to you! [the Pharisees] For you are like unmarked graves, and people walk over them without realizing it.'The latter saying differs quite dramatically from Matt. 23:27, but both sayings (Luke I r:44 and Matt. 23:27) presuppose that graves are inherently impure. 
to realize that people did not actively avoid impurity. In some cases, however, underlying scholarly biases towards purity laws play a part. Meier's conclusion is highly revealing in this regard. Summarizing his findings at the end of a substantial chapter on 'Jesus and Purity Laws' he states, 'the authentic Jesus tradition is completely silent on the topic of ritual purity', adding, 'apparently, for Jesus ritual purity is not a burning issue, it is not an issue at all'. Still, according to Meier (2009: 4I 4-I 5), Jesus' silence on the issue of purity is significant, a point that he stresses in his final conclusion: 'In short, Jesus' studied indifference to ritual impurity must be seen within this larger framework of his claim to be the charismatic prophet of the end time'. It is unclear how the silence on the topic of ritual purity translates into Jesus 'studied indifference'. Such a conclusion demonstrates a scholarly desire, unconscious or not, to attribute to Jesus a negative attitude towards purity laws.

Scholars rarely explain their own agendas when it comes to reconstructing the historical Jesus. Nevertheless, in some instances the reconstructions reveal negative attitudes towards purity laws on the part of the interpreters. For Marcus Borg (2007: I I 2-I3, I35-55), for example, purity stands at the opposite end of compassion, whereas Karen Wenell (2007: IOI) contrasts purity with love. For many feminist scholars, purity laws are seen as discriminatory against women (Getty-Sullivan 200r: 69). For some, notions of purity divide people into categories of pure and impure, whereas Jesus was inclusive of all (e.g., Dunn 2002: 467). In one strand of the scholarship on the historical Jesus, scholars go to great lengths to present Jesus' alleged negative attitude towards traditional purity laws as a part of his Jewishness. Jesus' rejection of purity laws and invention of a new process for transmitting purity becomes a 'redefinition' of traditional Jewish laws. For these scholars, Jesus' 'Jewishness' is central, but the religion of this Jew, in fact, has little in common with other strands of Judaism. Sanders includes purity concerns as a key component of common Judaism, that is, what everybody agreed upon. Given this definition of Judaism, one could say that the portrayal of a Jesus figure who rejects, or disregards, purity laws, is not very Jewish at all, at least not in a traditional sense. Such reconstruction would make him, in Crossley's terminology, 'Jewish, but not that Jewish'. In agreement with Arnal, I hold that it is important not to presuppose that Jesus could not have been a distinctive figure in some ways in the context of his environment, given that he started a movement that would eventually break away from Judaism. Nevertheless, the specifically distinctive traits of Jesus have to be found elsewhere; they cannot be detected in the area of purity. 
Cecilia Wassen is an Associate Professor of New Testament Exegesis at Uppsala University. She received her PhD in Early Judaism and Christian Origins from McMaster University. She is the author of Women in the Damascus Document (Society of Biblical Literature Academia Biblica Series, 21, SBL/Brill, 2005). She has written numerous articles on the Dead Sea Scrolls and the New Testament on topics such as purity laws, the historical Jesus, women and families, angels, and temple metaphors. She is the editor of several books, including The Scrolls from Qumran and the Concept of a Library (eds Sidnie W. Crawford and C. Wassen, Studies in the Texts of the Desert of Judah, 116, Brill, 2016) and Giving Thanks to the Lord: Essays on Prayer and Poetry in the Dead Sea Scrolls and Related Literature in Honor of Eileen Schuller on the Occasion of Her 65th Birthday (eds J. Penner, K. M. Penner, and C. Wassen, Studies in the Texts of the Desert of Judah, 98, Brill, 2011).

\section{Bibliography}

Adler, Yonatan, $20 \mathrm{I}$ I. The Archaeology of Purity: Archaeological Evidence for the Observance of Ritual Purity in 'Eres-Israel from the Hasmonean Period until the End of the Talmudic Period (164 B.C.E--400 C.E.), PhD dissertation (Bar Ilan University) (in Hebrew)

Alexander, Philip, I 986. Review of E.P. Sander's Jesus and Judaism, Journal of Jewish Studies, 37(I), pp. Iо3-6

Alon, Gedalyahu, I977. 'The bounds of the laws of Levitical cleanness' in Jerws, Judaism and the Classical World: Studies in Jewish History in the Times of the Second Temple and Talmud, trans. Israel Abrahams (Jerusalem, Magnes), pp. I 9o-234

Arnal, William, 2005. The Symbolic Jesus: Historical Scholarship, Judaism and the Construction of Contemporary Identity (London, Equinox)

Barclay, John M., I995. 'Deviance and apostasy: some applications of deviance theory to first-century Judaism and Christianity' in Modelling Early Christianity: Social-Scientific Studies of the New Testament in Its Context, ed. Philip F. Esler (London, Routledge), pp. I I 4-27

- 1996. Jews in the Mediterranean Diaspora: From Alexander to Trajan (323 BCE117 CE) (Berkeley, University of California Press)

Berlin, Andrea M., 2005. 'Jewish life before the revolt: the archaeological evidence', Journal for the Study of Judaism, 36, pp. 4 I 7-70

Bird, Michael F., 2008. 'Jesus as law breaker' in Who Do My Opponents Say That I am? An Investigation of the Accusations against Jesus, eds Scot McKnight and Joseph Modica, Library of New Testament Studies (London, T\&T Clark International), pp. 3-26

Booth, Roger, I 986. Jesus and the Laws of Purity: Traditions History and Legal History in Mark 7 (Sheffield, JSOT Press)

Borg, Marcus, 2007. Conflict, Holiness and Politics in the Teachings of Jesus, 2nd edn (Harrisburg, PA, Trinity Press)

Chilton, Bruce, 1992. The Temple of Jesus: His Sacrificial Program within a Cultural History of Sacrifice (University Park, Pennsylvania State University)

_ 1996. Pure Kingdom: Jesus' Vision of God (Grand Rapids, MI, Eerdmans)

- 1998. Jesus' Baptism and Jesus' Healing: His Personal Practice of Spirituality

(Harrisburg, PA, Trinity Press International) 
2000. Rabbi Jesus (New York, Doubleday)

Chilton, Bruce, and Jacob Neusner, I 995. Judaism in the New Testament (London, Routledge)

Cohen, Shaye 1999. The Beginnings of Jewishness: Boundaries, Varieties, Uncertainties (Berkeley, The University of California Press)

2008. 'Common Judaism in Greek and Latin sources' in Redefining First-Century Jewish and Christian Identities: Essays in Honor of Ed Parish Sanders, ed. Fabian

E. Udoh (Notre Dame, IN, University of Notre Dame Press), pp. 69-87

Crossan, John Dominic, I 99. The Historical Jesus: The Life of a Mediterranean Jewish Peasant (New York, Harper One)

Crossley, James G., 2004. The Date of Mark's Gospel: Insight from the Law in Earliest Christianity, JSNT Supplement, 246 (London, T\&T Clark)

-2006. Why Christianity Happened: A Sociohistorical Account of Christian Origins (26-50 CE) (Louisville, KY, Westminster John Knox Press)

2008. Jesus in the Age of Terror: Scholarly Projects for a New American Century (London, Equinox)

_2013. 'A "very Jewish" Jesus: perpetuating the myth of superiority', Journal for the Study of the Historical Jesus, I I, pp. Io9-29

Dunn, James D. G., 2002. 'Jesus and purity: an ongoing debate', Nerw Testament Studies, 48, pp. $449^{-67}$

-2003. Jesus Remembered, vol. I of Christianity in the Making (Grand Rapids, MI,

Eerdmans)

Evans, Craig, I 997. "Who touched me?” Jesus and the ritually impure' in Jesus in Context: Temple, Purity, and Restoration, eds Bruce D. Chilton and Craig A. Evans, (Leiden, Brill), pp. 353-76

Fletcher- Louis, Crispin, 2007. 'Jesus as the High Priestly Messiah: part 2', Journal for the Study of the Historical Jesus, 5( I), pp. 57-79

Fredriksen, Paula, I 999. Jesus of Nazareth: King of the Jews (New York, Vintage Books)

Furstenberg, Yair, 2008. 'Defilement penetrating the body: a new understanding of contamination in Mark 7.I 5', New Testament Studies, 54, pp. I 76-200

Hagner, Donald, I 997. The Jewish Reclamation of Jesus: An Analysis and Critique of the Modern Jewish Study of Jesus (Eugene, OR, Wipf and Stock Publishers)

Harrington, Hannah, 2004. Purity Texts (London, T\&T Clark)

Hengel, Martin, and Roland Deines, I 995 . 'E. P. Sanders' “Common Judaism”, Jesus, and the Pharisees', Journal of Theological Studies, 46, pp. I-70

Heschel, Susannah, 2009. The Aryan Jesus: Christian Theologians and the Bible in Nazi Germany (Princeton University Press)

Holmén, Tom, 200ra. 'The Jewishness of Jesus in the "Third Quest"' in Jesus, Mark, and Q: The Teaching of Jesus and its Earliest Records, eds Michael Labahn and Andreas Schmidt, JSNT Supplement, 2 I 4 (Sheffield University Press), pp. I43-62

200 Ib. Jesus and Jewish Covenant Thinking, Biblical Interpretation Series, 55

(Leiden, Brill) 
20 I I. 'Jesus and the purity paradigm' in Handbook for the Study of the Historical Jesus, vol. 3, eds Tom Holmén and S. E. Porter (Leiden, Brill), pp. 2709-44

_-2013. "Jesus of context": putting perspective in perspective' in Jesus. Gestalt und Gestaltungen: Rezeptionen des Galiläers in Wissenschaft, Kirche und Gesellschaft Festschrift für Gerd Theissen zum 70. Geburtstag (Göttingen, Vandenhoeck \& Ruprecht), pp. 5 I5-35

Hørning Jensen, Morten, 20 I 3. 'Purity and politics in Herod Antipas's Galilee: the case for religious motivation', Journal for the Study of the Historical Jesus, I I (I), pp. 3-34

Getty-Sullivan, Mary Ann, 200 I. Women in the New Testament (Collegeville, MN, Liturgical Press)

James, Marisa Elana, 20 I2. 'The Jew who pulled down the walls: Tiberius Julius between Alexandria and Jerusalem', Rabbinic Civ. I final paper, I 9.I.20 I 2, <https://www. academia.edu/2543723/The_Jew_who_Pulled_Down_the_Walls_Tiberius_ Julius_between_Alexandria_and_Jerusalem> (accessed 28.1.2016)

Kazen, Thomas, 2002. Jesus and Purity Halakbah: Was Jesus Indifferent to Impurity? Coniectanea Biblica New Testament Series, 38 (Stockholm, Almqvist \&Wiksell)

- 20 I o. Issues of Impurity in Early Judaism, Coniectanea Biblica New Testament Series, 45 (Winona Lake, IN, Eisenbrauns)

- 2013. Scripture, Interpretation, or Authority? Motives and Arguments in Jesus' Halakic Conflicts, Wissenschaftliche Untersuchungen zum Neuen Testament, 320 (Tübingen, Mohr Siebeck)

Klawans, Jonathan, 2006. 'Moral and ritual purity' in The Historical Jesus in Context, ed. Amy-Jill Levine, Dale C. Allison Jr., and John D. Crossan (Princeton University Press)

Knoppers, Gary, 201 3. Jews and Samaritans: The Origins and History of their Early Relations (Oxford University Press)

Levine, Amy-Jill, I 996. 'Discharging responsibility: Matthean Jesus, biblical law, and hemorrhaging woman' in Treasures New and Old: Recent Contributions to Matthean Studies, eds David R. Bauer and Mark Allen Powell (Atlanta, GA, Scholars Press), pp. 379-97

- 2007. Jesus the Misunderstood Jerw: The Church and the Scandal of the Jewish Jesus

(New York, HarperOne)

Luomanen, Petri, 2002. 'The "sociology of sectarianism" in Matthew: modelling the genesis of early Jewish and Christian communitites' in Fair Play: Diversity and Conflict in Early Christianity. Essays in Honour of Heikki Räisänen, eds Ismo Dunderberg, Christopher Tucket, and Kari Syreeni (Leiden, Brill), pp. 107-30

Meier, John P., I 99I-2009. A Marginal Jerw: Rethinking the Historical Jesus Jesus, 4 vols (New York, Doubleday)

Milgrom, Jacob, r 99 r. Leviticus 1-16, Anchor Bible (New York, Doubleday)

Mizzi, Dennis, (forthcoming). Qumran and the Dead Sea Scrolls: An Archaeology, Studies in the Texts of the Desert of Judah (Leiden, Brill, forthcoming in 201 7) 
Möller, Hilde Brekke, 20 I 5. The Vermes Quest: The Significance of Geza Vermes for Jesus Research, PhD dissertation (MF Norwegian School of Theology)

Neusner, Jacob, I978. Review of E. P. Sanders, Paul and Palestinian Judaism, History of Religions, I8(I), pp. I77-9I

I 984 . 'The formation of ancient rabbinic Judaism: Yavneh (Jamnia) from 70 AD to Ioo', in Aufstieg und Niedergang der Römischen Welt II, I 9(2), pp. 3-42

Pearson, Birger, 1996. The Gospel According to the Jesus Seminar, Occasional Papers of the Institute of Aniquity and Christianity, 35 (The Claremont Graduate School)

Perrin, Norman, I967. Rediscovering the Teaching of Jesus (London, SCM)

Räisänen, Heikki, 1982. 'Jesus and the food laws: reflections on Mark 7: I 5', Journal for the Study of the New Testament, I6, pp. 79-100

Runesson, Anders, 201 I . 'Judging Gentiles in the Gospel of Matthew: between 'othering' and inclusion' in Jesus, Mattherw's Gospel and Early Christianity Studies in Memory of Graham N. Stanton, eds Daniel M. Gurtner et al., The Library of New Testament Studies, 435 (London, T\&T Clark), pp. I 33-5 I

Sanders, E. P., I 985 . Jesus and Judaism (Philadelphia, Fortress Press)

- 1992. Judaism Practice and Belief 63 BCE-66 CE (London, SCM Press)

-2002. 'Jesus, ancient Judaism, and modern Christianity: the quest continues' in Jesus, Judaism, and Christian Anti-Judaism: Reading the New Testament after the Holocaust (Louisville, KY, Westminster John Knox), pp. 3 I-5 5

-2008. 'Common Judaism explored' in Common Judaism: Explorations in SecondTemple Judaism, eds Wayne O. McCready and Adele Reinhartz (Minneapolis, Fortress Press, 2008), pp. I I-23, 228-32

Smith, Jonathan Z., I 980. 'Fences and neighbors: some contours of early Judaism' in Approaches in Ancient Judaism, vol. 2, ed. W. Scott Green (Chico, CA, Scholars Press), pp. I-25

Svartvik, Jesper, 2000. Mark and Mission: Mk 7.1-23 in its Narrative and Historical Contexts, Coniectanea Biblica New Testament Series, 32 (Stockholm, Almqvist \& Wiksell)

Vermes, Geza, I 973. Jesus the Jerw: A Historian's Readings of the Gospels (London, Collins) Wassen, Cecilia, 2008. 'Jesus and the hemorrhaging woman in Mark 5:24-34: insights from purity laws from Qumran' in Scripture in Transition: Essays on Septuagint, Hebrew Bible, and Dead Sea Scrolls in Honour of Raija Sollamo, eds Anssi Voitila and Jutta Jokiranta, Supplements to the Journal for the Study of Judaism, I 26 (Leiden, Brill), pp. 64 I-60

-2016. 'Jesus' work as a healer in light of Jewish purity laws' in Bridging between Sister Religions: Studies of Jewish and Christian Scriptures Offered to Honor Prof. John Townsend, ed. Isaac Kalimi, Brill's Reference Library of Judaism (Leiden, Brill, forthcoming)

Wenell, Karen, 2007. Jesus and Land: Sacred and Social Space in Second Temple Judaism, Library of New Testament Studies, 334 (London, T\&T Clark)

Wright, N. T., I 996. Jesus and the Victory of God (London, SPCK) 